\title{
Effect of Planting Geometry and Nutrient Levels on the Productivity of Buckwheat
}

\author{
U.K. Hulihalli* and Shantveerayya \\ Directorate of Research, University of Agricultural Sciences, \\ Dharwad - 580 005, Karnataka, India \\ *Corresponding author
}

\section{A B S T R A C T}

\section{Keywords}

Primary branches, LAI, Nodes per plant, Clusters per plant, Buckwheat

Article Info

Accepted:

26 January 2018

Available Online:

10 February 2018

\begin{abstract}
A field experiment was conducted at Main Agricultural Research Station, University of Agricultural Sciences, Dharwad, Karnataka during kharif season of 2016-17 to study the effect of plant spacing and different levels of nutrients on the productivity of buckwheat. The experiment was laid out in split plot design with three replications. The treatments comprised of three plant spacing as main plot viz., $30 \times 10 \mathrm{~cm}, 30 \times 15 \mathrm{~cm}$ and $30 \times 20$ $\mathrm{cm}$ and three nutrient levels as sub plot viz., 35:20:20 NPK kg ha ${ }^{-1}, 35: 15: 15 \mathrm{NPK} \mathrm{kg} \mathrm{ha}^{-1}$ and 25:10:10 NPK kg ha ${ }^{-1}$. Among the plant spacing, significantly taller plant height (73.2 $\mathrm{cm})$, LAI (2.3), clusters per plant (5.2), seeds per cluster (8.3), grain yield (6.2 $\left.\mathrm{q} \mathrm{ha}^{-1}\right)$ and straw yield $\left(10.3 \mathrm{q} \mathrm{ha}^{-1}\right)$ was observed with spacing of $30 \mathrm{X} 10 \mathrm{~cm}$. Among the nutrient levels, application of 35:20:20 NPK kg ha ${ }^{-1}$ recorded significantly LAI (2.5), nodes plant ${ }^{-1}$ (20.4), clusters per plant (5.0), seeds per cluster (8.5), test weight $(26.6 \mathrm{~g})$, grain yield (6.0 $\left.\mathrm{q} \mathrm{ha}^{-1}\right)$ and straw yield $\left(10.2 \mathrm{q} \mathrm{ha}^{-1}\right)$.
\end{abstract}

\section{Introduction}

Buckwheat (Fagopyrum species) is an old traditional underutilized crop plant belonging to the family Polygonaceae that been used as staple food for local communities in India, Nepal, Bhutan and China predominantly in the hilly and temperate area of Europe and East Asia. It is curative herb or feed for animals long back until the expansion and industrialization of agriculture masked this crop and left behind all its significance, advantages and potential in the race towards the maximum amount producing crops. It grows well in all areas with low fertile soil, limited rainfall, used as a green manure and plant for erosion control thus, source of income for farmers. Buckwheat is eaten during fasting in India considering it to be a fruit not as a grain. Buckwheat grains are an important source of macro elements such as K, $\mathrm{Ca}, \mathrm{Mg}$, and $\mathrm{Na}$ as well as micro elements such as $\mathrm{Mn}, \mathrm{Zn}, \mathrm{Se}$, and $\mathrm{Cu}$ (Wei et al., 2003), and they contain rutin, riboflavin, pyridoxine, thiamine, lysine, methionine, arginine, and threonine (Fabjan et al., 2003).

A crop would express its full potential only when it is backed up by good agronomic practices. Optimum plant density provides 
conditions for proper light interception throughout the crop growth period. Further, it is important to realize that plant density should be defined not only in terms of number of plants per unit area but also in terms of arrangement of these plants on the ground (planting geometry/spatial arrangement) as it helps in efficient harvesting of solar energy with least competition for growth factors viz., water and nutrient uptake which ultimately decides the expression of phenotypic and genotypic character of the crop. All these factors influence the crop growth, seed yield and quality parameters.

Nutrients are important and crucial elements, which are required for the plant for its growth and development. The translocation of photosynthates from source to sink is very important for the development of economic part. One of plant's basic elements is nitrogen. Buckwheat response to nitrogen depends on primary nitrogen content of the soil, climatic conditions and nitrogen additives as well as its addition time.

\section{Materials and Methods}

To study on evaluation of plant density and nutrient levels on growth and yield of Buck wheat, the field experiment was carried out at Main Agricultural Research Station, Dharwad, Karnataka during the kharif season of 201617. The Station located between $15^{0} 30^{1} 6^{11}$ North latitude and at longitude of $74^{0} 59^{1} 12.4^{11}$ East at an attitude of $678 \mathrm{~m}$ above MSL. The Experiment was laid out in split plot design with three replications having three planting densities viz., $S_{1}-30 \times 10 \mathrm{~cm}, S_{2}-30 \times 15 \mathrm{~cm}$ and $S_{3^{-}} 30 \times 20 \mathrm{~cm}$ as main plots, three nutrient level viz., $\mathrm{F}_{1}-35: 20: 20 \mathrm{NPK} \mathrm{kg} \mathrm{ha}{ }^{-1}$, $F_{2}-35: 15: 15$ NPK kg ha ${ }^{-1}$ and $F_{3}-25: 10: 10$ NPK $\mathrm{kg} \mathrm{ha}^{-1}$ as sub plots.

Plant height was measured by taking five plants randomly from individual plant and measured in centimetre from the ground level. Lead Area Index (LAI) was calculated by disc method as suggested by Vivekanandan et al., (1972). The full amount of phosphorus and potash and a half of the nitrogen per treatment was applied at the time of sowing. The remaining half of the nitrogen was applied 30 days after sowing. Other crop management practices were carried out in accordance with local agronomic practices. Crop was harvested at physiological maturity stage. After harvesting, the plants were bundled and allowed for sun drying. The grains were separated from the dried plants by threshing and winnowing. Grains from individual plots were cleaned, dried and weight was recorded. The data collected from the experiment at different growth stages and at harvest was subjected to statistical analysis as described by Gomez and Gomez (1984).

\section{Results and Discussion}

Climatic conditions, soil type, location, sowing time and varieties will determine the optimum planting density. Among the planting geometry, taller plants were recorded at a spacing of $30 \times 10 \mathrm{~cm}$ at harvest $(73.2 \mathrm{~cm})$ and it was on par with spacing of $30 \times 15 \mathrm{~cm}$ $(71.5 \mathrm{~cm})$ compared to $30 \times 20 \mathrm{~cm}(68.0 \mathrm{~cm})$ (Table 1). This was due to less inter-plant competition for light. A possible reason for increased accumulation is that the more number of plants per unit area increased both the photosynthesizing area and the volume of roots per unit soil surface, allowing the crop to improve the exploitation of environmental resources. Lower light interception at wider row spacing could have reduced assimilate production (Amjad and Anderson, 2006).

Significantly higher leaf area index (2.3) was recorded when plants were grown with spacing of $30 \times 10 \mathrm{~cm}$ and it was on par with spacing of $30 \times 15 \mathrm{~cm}$ compared to spacing of 30 X $20 \mathrm{~cm}$ (1.7) (Table 1). A possible reason 
for increased LAI was due to optimum plant density and optimum row spacing improves the light interception which ultimately results in the increased interception of photo synthetically active radiation. At higher densities, canopy allows for more efficient light interception and penetration which consequently results in higher photosynthetic rates specifically at leaves located in the lower portion of the canopy. Significantly higher primary branches plant ${ }^{-1}$, nodes plant $^{-1}$ and petiole length was recorded in the spacing of $30 \times 10 \mathrm{~cm}$ (5.6, 19.5 and 6.2, respectively) and it was on par with spacing of $30 \times 15 \mathrm{~cm}$ (5.1, 18.0 and 6.0, respectively). This was due to optimum availability of all resources. Although primary branches, nodes and petiole length is a varietal character, but it is also influenced by temperature, humidity and better crop management.

The planting density of $30 \times 10 \mathrm{~cm}$ produced significantly higher grain (6.2 $\left.\mathrm{q} \mathrm{ha}{ }^{-1}\right)$ and straw yield (10.3 $\left.\mathrm{q} \mathrm{ha}^{-1}\right)$ and it was on par with spacing of $30 \times 15 \mathrm{~cm}\left(5.8\right.$ and $9.1 \mathrm{q} \mathrm{ha}^{-1}$, respectively) (Table 2). This was mainly due to more efficient use of light in photosynthesis, better resource availability and reduced interplant competition in the community. Increase in grain yield was due to increase in yield attributes viz., number of clusters per plant, seeds per cluster and test weight. At spacing of $30 \times 10 \mathrm{~cm}$ recorded significantly more number of clusters per plant (5.2), seeds per cluster (8.3) and test weight $(25.4 \mathrm{~g})$ compared to $30 \mathrm{X} 15 \mathrm{~cm}$ and $30 \times 20$ $\mathrm{cm}$. The impact of row spacing on yield varies depending on the growing season of rainfall. Narrow row spacing recorded significantly higher moisture content in comparison to wide row spacing as former spacing reduced evaporation by increasing the rate of canopy closure (Anjhu Jeorge, 2014).The improvement in grain production with narrow row spacing could be attributed to higher planting density. Planting at a spacing of $30 \mathrm{X}$
$10 \mathrm{~cm}$ recorded significantly higher grain yield compared to $30 \times 20 \mathrm{~cm}$. This increase in yield due to lesser spacing can be attributed to more plant population per unit area, which also reflected in higher values of growth attributing parameters viz. plant height and leaf area index and yield parameters like clusters per plant, seeds per cluster and 1000 grain weight. Similar results were reported by Paynter (2010), Kleemann and Gill (2010) and Anjhu Jeorge, (2014) in barley.

Nutrient supply is one of the most important factors that determines the growth of the crop. Fertilizer is the major plant food required in sufficient quantity. The response of crop to fertilizers varies widely from place to place, depending upon the native fertility level of soil, environmental condition and genotype. Among the nutrient levels, significantly taller plant height $(75.0 \mathrm{~cm})$ and higher LAI (2.5) (Table 1) was observed in the application of 35:20:20 NPK kg ha-1 and it was on par with the application of $35: 15: 15 \mathrm{NPK} \mathrm{kg} \mathrm{ha}{ }^{-1}$ this was due to higher uptake of nitrogen and phosphorus (Yadravi and Angadi, 2015). Increase in LAI was closely attributed due to higher leaf area per plant and number of leaves per plant. This is directly related to the higher plant height (Karki et al., 2005 and Arun Kumar et al., 2007).

Data regarding primary branches plant -1, nodes plant-1 and petiole length of common buck wheat as affected by various nitrogen and phosphorus levels is presented in Table 1. The table shows that nitrogen and phosphorus levels affected number of primary branches plant $^{-1}$ nodes plant ${ }^{-1}$ and petiole length of buckwheat significantly. Maximum number of primary branches plant ${ }^{-1}(5.7)$, nodes plant $^{-1}$ (20.4) and petiole length $(6.6 \mathrm{~cm})$ was produced in plots which received 35:20:20 NPK $\mathrm{kg} \mathrm{ha}^{-1}$ and it was on par with application of $35: 15: 15$ NPK kg ha ${ }^{-1}$ (5.4, 18.3 and $6.2 \mathrm{~cm}$, respectively). 
Table.1 Effect of spacing and nutrient levels on plant height, LAI, primary branches plant ${ }^{-1}$, nodes plant ${ }^{-1}$ and petiole length of buck wheat.

\begin{tabular}{|c|c|c|c|c|c|}
\hline Treatment & $\begin{array}{l}\text { Plant height } \\
\text { at harvest } \\
(\mathrm{cm})\end{array}$ & LAI & $\begin{array}{c}\text { Primary } \\
\text { branches }^{\text {plant }}{ }^{-1}\end{array}$ & $\underset{-1}{\text { Nodes plant }}$ & $\begin{array}{c}\text { Petiole } \\
\text { length }(\mathrm{cm})\end{array}$ \\
\hline \multicolumn{6}{|l|}{ Main plot - Spacing (S) } \\
\hline $30 \times 10 \mathrm{~cm}(\mathrm{~S} 1)$ & 73.2 & 2.3 & 5.6 & 19.5 & 6.2 \\
\hline $30 \times 15 \mathrm{~cm}(\mathrm{~S} 2)$ & 71.5 & 2.1 & 5.1 & 18.0 & 6.0 \\
\hline 30 X 20 cm (S3) & 68.0 & 1.7 & 4.5 & 14.7 & 5.6 \\
\hline S.Em \pm & 0.87 & 0.07 & 0.17 & 0.89 & 0.10 \\
\hline CD@ 5\% & 3.41 & 0.28 & 0.68 & 3.49 & 0.39 \\
\hline \multicolumn{6}{|l|}{ Sub plot - Fertilizer $(\mathbf{F})$} \\
\hline $35: 20: 20$ NPK kg ha ${ }^{-1}(\mathrm{~F} 1)$ & 75.0 & 2.5 & 5.7 & 20.4 & 6.6 \\
\hline 35:15:15 NPK kg ha ${ }^{-1}$ (F2) & 73.0 & 2.2 & 5.4 & 18.3 & 6.2 \\
\hline 25:10:10 NPK kg ha ${ }^{-1}(\mathrm{F3})$ & 64.7 & 1.4 & 4.1 & 13.5 & 5.0 \\
\hline S.Em \pm & 2.66 & 0.26 & 0.42 & 1.34 & 0.40 \\
\hline CD@ 5\% & 8.20 & 0.80 & 1.28 & 4.13 & 1.23 \\
\hline \multicolumn{6}{|l|}{ Interaction - S X F } \\
\hline S1F1 & 77.6 & 3.0 & 6.3 & 22.1 & 7.0 \\
\hline S1F2 & 75.3 & 2.5 & 6.0 & 20.9 & 6.5 \\
\hline S1F3 & 66.7 & 1.5 & 4.5 & 15.5 & 5.2 \\
\hline S2F1 & 75.7 & 2.6 & 5.9 & 21.5 & 6.6 \\
\hline S2F2 & 73.2 & 2.3 & 5.4 & 18.5 & 6.3 \\
\hline S3F3 & 65.6 & 1.3 & 4.2 & 14.1 & 5.0 \\
\hline S3F1 & 71.6 & 2.1 & 5.1 & 17.6 & 6.1 \\
\hline S3F2 & 70.4 & 1.9 & 4.8 & 15.5 & 5.9 \\
\hline S3F3 & 61.9 & 1.3 & 3.5 & 10.9 & 4.7 \\
\hline S.Em \pm & 4.61 & 0.45 & 0.72 & 2.32 & 0.69 \\
\hline CD@ 5\% & NS & NS & NS & NS & NS \\
\hline
\end{tabular}


Table.2 Effect of spacing and nutrient levels on clusters per plant, seeds per cluster, test weight, grain yield and straw yield of buck wheat

\begin{tabular}{|c|c|c|c|c|c|}
\hline Treatment & $\begin{array}{l}\text { Clusters } \\
\text { per plant }\end{array}$ & $\begin{array}{l}\text { Seeds per } \\
\text { cluster }\end{array}$ & $\begin{array}{l}\text { 1000-seed } \\
\text { weight (g) }\end{array}$ & $\begin{array}{l}\text { Grain yield } \\
\qquad\left(\mathrm{q} \mathbf{h a}^{-1}\right)\end{array}$ & $\begin{array}{l}\text { Straw yield } \\
\qquad\left(\mathbf{q} \mathbf{h a}^{-1}\right)\end{array}$ \\
\hline \multicolumn{6}{|l|}{ Main plot - Spacing (S) } \\
\hline $30 \times 10 \mathrm{~cm}(\mathrm{~S} 1)$ & 5.2 & 8.3 & 25.4 & 6.2 & 10.3 \\
\hline 30 X 15 cm (S2) & 4.9 & 8.2 & 23.9 & 5.8 & 9.1 \\
\hline 30 X 20 cm (S3) & 4.3 & 7.6 & 22.0 & 4.4 & 7.6 \\
\hline S.Em \pm & 0.09 & 0.11 & 0.52 & 0.35 & 0.44 \\
\hline CD@ 5\% & 0.33 & 0.43 & 2.06 & 1.36 & 1.72 \\
\hline \multicolumn{6}{|l|}{ Sub plot - Fertilizer (F) } \\
\hline 35:20:20 NPK kg ha-1 (F1) & 5.0 & 8.5 & 26.6 & 6.0 & 10.2 \\
\hline 35:15:15 NPK kg ha (F2) $^{-1}$ & 4.9 & 8.1 & 25.1 & 5.7 & 9.3 \\
\hline 25:10:10 NPK kg ha ${ }^{-1}$ (F3) & 4.4 & 7.4 & 19.6 & 4.6 & 7.5 \\
\hline S.Em \pm & 0.14 & 0.22 & 1.56 & 0.33 & 0.38 \\
\hline CD@ 5\% & 0.44 & 0.69 & 4.80 & 1.01 & 1.19 \\
\hline \multicolumn{6}{|l|}{ Interaction - S X F } \\
\hline $\begin{array}{r}\text { S1F1 } \\
\end{array}$ & 5.3 & 8.8 & 28.4 & 6.9 & 11.6 \\
\hline S1F2 & 5.4 & 8.5 & 26.1 & 6.4 & 10.7 \\
\hline S1F3 & 4.9 & 7.5 & 21.6 & 5.2 & 8.5 \\
\hline S2F1 & 5.1 & 8.8 & 26.6 & 6.4 & 10.5 \\
\hline S2F2 & 5.0 & 8.2 & 25.6 & 6.1 & 9.1 \\
\hline S3F3 & 4.5 & 7.5 & 19.4 & 5.0 & 7.8 \\
\hline S3F1 & 4.5 & 8.0 & 24.7 & 4.8 & 8.4 \\
\hline S3F2 & 4.4 & 7.6 & 23.6 & 4.7 & 8.2 \\
\hline S3F3 & 3.9 & 7.2 & 17.8 & 3.6 & 6.4 \\
\hline S.Em \pm & 0.25 & 0.39 & 2.70 & 0.57 & 0.67 \\
\hline CD@ 5\% & NS & NS & NS & NS & NS \\
\hline
\end{tabular}

While the lowest number of branches plant ${ }^{-1}$ (4.1), nodes plant ${ }^{-1}$ (13.5) and petiole length (5.0) was recorded in plots where 25:10:10 NPK kg ha ${ }^{-1}$ was applied.

Grain yield and straw yield of common buckwheat as affected by nitrogen and phosphorus levels is shown in Table 2. The table shows that various $\mathrm{N}$ and $\mathrm{P}$ levels affected grain yield of buckwheat significantly. Significantly higher grain and straw yield (6.0 and $10.2 \mathrm{q} \mathrm{ha}^{-1}$, respectively) was produced in plots which received 35:20:20 NPK kg ha-1 and it was on par with application of $35: 15: 15$ NPK kg ha ${ }^{-1}$ (5.7 and
$9.3 \mathrm{q} \mathrm{ha}^{-1}$, respectively) while the lowest grain and straw yield (4.6 and $7.5 \mathrm{q}$ ha -1 , respectively) was produced in plots in which 25:10:10 NPK kg ha-1 was applied. This was due to significant increment in yield attributes viz., more number of clusters per plant (5.0), seeds per cluster (8.5) and test weight (26.6 g). These results are in concurrence with the findings of Noworolink, (1995). The higher grain and straw yield of buckwheat was mainly due to better translocation of photosynthates from source to sink and higher growth and yield attributing characters. Increase in yield may be attributed to application of nitrogen accelerated the 
photosynthetic rate resulted in the improvement of growth and yield components (Shah Khalid et al., 2015). The increase in number of clusters per plant attributed due to nitrogen involved in energy transformations, activation of enzymes in carbohydrate metabolism and consequently greater transformation of photosynthates into reproductive parts (Mohammadi et al., 2015 and Zhang et al., 2013). Interaction effects were non-significant with respect to planting density, genotypes and nutrient management.

\section{References}

Anjhu George, 2014. M. Sc. (Agri) Thesis, Univ. Agric. Sci., Dharwad, Karnataka (India)

Arun Kumar, M.A. Gali, S.K. and Patil, R.V.2007. Effect of level of NPK on quality of sweet corn grown on vertisol. Karnataka $J$. Agric.Sci. 20(1): $44-46$.

Fabjan, N., Rode, J., Košir, I.J., Wang, Z.H., Zhang, Z. and Kreft, I. 2003. Tartary buckwheat (Fagopyrum tataricum Gaertn.) as a source of dietary rutin and quercitrin. $J$. Agric. Food Chem. 51: 6452-6455.

Gomez, K. A. and Gomez, A. A., 1984. Statistical Procedures for Agricultural Research, $2^{\text {nd }}$ Edition, A Wiley Inter Science Publications, New York, USA.

Inamullah, Ghulamullah Saqib, Muhammad Ayub, Asad Ali Khan, Shazma Anwar and Shah Alam Khan. Sarahad. 2012. Response of Common Buckwheat to Nitrogen and Phophorus fertilization J. Agric.28 (2): 18-24

Karki, T.B, Ashok Kumar and Guatam, R.C., 2005. Influence of Integrated nutrient management on growth, yield, uptake of nutrients and soil fertility status of maize. Indian. J.Agric.Sci. 75(10): 682-685

Kleemann, S. G. L. and Gill, G. S., 2010, Influence of row spacing on water use and yield of rain-fed wheat (Triticum aestivum L.) in a no-till system with stubble retention. Crop Pasture Sci., 61(11): 892-898.

Mohammadi, T., Nazaryan, R. and Kobraee, S., 2015. The response of chlorophyll and protein concentration in winter wheat to different levels of irrigation and nitrogen application. Int. J. Bio. Pharmacy Allied Sci., 4 (6): 38263833.

Noworolnik, K., 1995. Nitrogen fertilization efficiency of buckwheat grown at various soil conditions. The 6th international symposium on buckwheat. Cur. Adv. Buckwheat Res, 601604.

Paynter, B. H., 2010. Wide Row Spacing and Rigid Ryegrass (Lolium rigidum) Competition Can Decrease Barley Yield. Weed Tech., 24(3): 310-318.

Shah Khalid, Fazal Munsif, Amjid Ali, Muhammad Ismail and Noorul Haq and Shahid. 2015. Evaluation of chip bud settling of sugarcane for enhancing yield to various row spacing. Int. J. Agric. Env. Res: 1(2): 8-13

Vivekanandan, A. S., Gunasena, P. M. and Sivanayagam, T. M., 1972. Statistical evaluation of accuracy of the techniques used in the estimation of leaf area of crop plants. Indian J. Agric. Sci., 42: 857-860.

Wei, Y.M., Hu, X.Z., Zhang, G.Q. and Ouyang, S.H. 2003. Studies on the amino acid and mineral content of buckwheat protein fractions. Food/Nahrung 47: 114-116.

Yadravi, M. and Angadi, V. V., 2015. Effect of time and method of application of varied levels of nitrogen in soybean. M. Sc. (Agri.) Thesis, Univ. Agric. Sci., Dharwad. Karnataka (India).

Zhang, X., Huang, G., Bian, X. and Zhao, Q., 2013. Effects of root interaction and nitrogen fertilization on the chlorophyll content, root activity, photosynthetic characteristics of intercropped soybean and microbial quantity in the Rhizosphere. Plant soil Env., 59 (2): 8088.

\section{How to cite this article:}

Hulihalli, U.K. and Shantveerayya. 2018. Effect of Planting Geometry and Nutrient Levels on the Productivity of Buckwheat. Int.J.Curr.Microbiol.App.Sci. 7(02): 3369-3374. doi: https://doi.org/10.20546/ijcmas.2018.702.403 